REVISTA CHILENA DE LITERATURA

Noviembre 2008, Número 73, 189 - 215

\title{
EL DELIRIO QUE VIENE DE LAS NINFAS EN LA NOVELA LATINOAMERICANA: "NADA MÁS QUE SER FELIZ"
}

\author{
Mario Rodríguez \\ y José Manuel Rodríguez \\ Universidad de Concepción
}

RESUMEN / ABSTRACT

\begin{abstract}
Explorando el panoptismo en la novela hispanoamericana, nos encontramos con una figura inesperada, la de las ninfas, figura no prevista en la investigación. No fue un encuentro buscado, sino una constatación no vista hasta ahora: las figuras femeninas paradigmáticas del relato de vanguardia (La Maga, La Eterna, Beatriz, Brígida, Elsa, por ejemplo) son categóricamente ninfas. Todas ellas aparecen inseparables de elementos acuáticos y vegetales (como la dríade Brígida de El árbol de María Luisa Bombal). En sentido estricto forman "agenciamientos" con ríos, fuentes, árboles y flores.
\end{abstract}

PALABRAS ClAVE: panoptismo, fractura, ninfas, pensamiento otro, utopía.

When exploring panopticism in Latin American novels, we encountered an unexpected image, that of the nymphs, an image we had not accounted for in our research. We had not looked for nymphs, a figure nor previously present in earlier readings of these novels; but those paradigmatic feminine figures in avant-garde narratives (La Maga, La Eterna, Beatriz, Brígida, Elsa) can categorically be described as nymphs. They are inseparable from aquatic and vegetal elements (like the driade Brigida in El árbol by María Luisa Bombal). They actuate through the medium of rivers, fountains, trees and flowers.

KEY WORDS: Panopticism, fracture, nymphs, alterative thinking, utopia. 
Para Rubén Darío

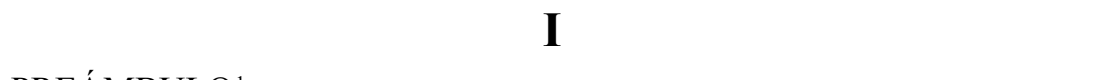

\section{PREÁMBULO ${ }^{1}$}

El concepto de “panóptico”, empleado en el siglo XVIII por Jeremías Bentham para designar una construcción arquitectónica carcelaria, fue reelaborado por Michel Foucault en Vigilar y Castigar para pensar "un modelo generalizable de funcionamiento, una nueva manera de definir las relaciones de poder en la vida cotidiana de los hombres" (56). Nosotros lo proyectamos a la literatura en un nivel no previsto por el filósofo al considerar al narrador omnisciente, el de la novela realista por ejemplo, como un narrador panóptico cuya función, luego de instalarse en un lugar donde todo lo ve, es, precisamente, vigilar a sus personajes, castigar a los transgresores de toda norma y premiar a los que la acatan. Surge así la denominación "novela panóptica”, desarrollada en el texto Utopía y mentira de la novela panóptica.

Buscando un espacio textual en que se fracture el panóptico nos encontramos con la novela de (pos)vanguardia latinoamericana. Ellas representarían una escritura en que se desintegra el orden panóptico. Para mostrar cómo ocurre tal desintegración usamos algunos autores de "culto", como Macedonio Fernández, Roberto Arlt, Adolfo Bioy Casares y otros. De "culto" por su recepción minoritaria y porque han sido objeto de lecturas fervientes y continuas de otros autores paradigmáticos de nuestra literatura, ciertamente más divulgados, como Jorge Luis Borges y Ricardo Piglia.

El desmoronamiento del panoptismo asumirá en la vanguardia múltiples formas. En un principio nos proponíamos estudiar cuatro de ellas:

1. El desplazamiento, en el nivel del narrador, desde la figura del Gran Vigilante (el ojo del panóptico, temeroso de contagiarse de los deseos transgresivos de sus personajes) hasta la figura del "traidor". Narrador

1 Este trabajo se escribió en el marco de una colaboración entre los proyectos Fondecyt 106077 y 3080035 titulados respectivamente: "Panoptismo y antipanoptismo en la novela hispanoamericana" y "Las ninfas, la literatura y el narrador". 
que para escribir "traiciona" su lengua, su clase social, incluso su sexo.

2. La irrupción del relato fantástico como forma de emancipación de lo reprimido.

3. La invención de "ciudades ausentes". Invención que se conecta a la afirmación propuesta por Deleuze en Crítica y Clínica: "Objetivo último de la literatura: poner de manifiesto en el delirio esta creación de salud, o esta invención de un pueblo, es decir, una posibilidad de vida. Escribir para ese pueblo que falta" (16).

4. La práctica de la literatura como escritura de una lectura en la que escribir deviene "robo", "traición", asume las formas del "libertinaje literario" propuesto por Sarmiento o las de "visión estrábica", presente en Respiración artificial donde la mirada de Piglia se posa en dos Argentinas simultáneamente, la de Rozas en el siglo XIX y la del "Proceso" (la dictadura militar) en el siglo XX.

Este era el plan. Sin embargo, surgió de las novelas elegidas algo inesperado: la figura seductora de una ninfa emergiendo desde el fondo del tiempo, del milenario encrespamiento de unas aguas elementales ¿Cómo pudo ocurrir algo tan fuera del canon de la investigación?... Las "culpables", si así pueden llamarse, de tan sorprendente asociación fueron ciertas palabras, vinculadas reiteradamente a las figuras femeninas de los relatos vanguardistas, agua, árboles, flores, fuentes.

En la ficción de (pos)vanguardia las mujeres llegan a establecer verdaderos "agenciamientos" con estos elementos acuáticos y vegetales. Separarlas de ellos significa traicionar la funcionalidad de su fascinante presencia.

Ante la inseparabilidad, solo cabe preguntarse de dónde proviene esta unión, algo así como interrogarse por su origen, y quién o quiénes son el (o los) paradigma(s) de su representación. No cabía otra respuesta que las ninfas. $\mathrm{Su}$ fascinante figura, desde los mitos griegos hasta los imaginarios modernos, ha estado siempre unida a las flores, las fuentes, los bosques. La ninfa emergiendo gloriosamente de las ondas ha sido una imagen que ha cautivado el ojo del pintor, la palabra del poeta y el corazón de los amantes.

Practicando el "estrabismo", sin desviar la mirada sobre las ninfas para posarla simultáneamente en el objeto opuesto de la ficción, los héroes masculinos, pudimos percibir en ellos algo innegable: ellos parecieran "capturados", "raptados", por las ninfas. Casos paradigmáticos, el de Oliveira capturado por la Maga y el de Endorsain por Elsa. 
¿Qué significa en los textos de Cortázar y de Arlt estar “capturado” por las ninfas? Más allá de la evidente atracción erótica, nivel de por sí rudimentario, representaría la posibilidad de acceder a otro modo de pensar. En rigor, un pasaje a la otredad. Este nuevo conocimiento se origina cuando las ninfas capturan las mentes de los héroes novelescos, para desatar en ellas devenires mentales vertiginosos que desterritorializan bloques de vida rutinaria y dispositivos del poder.

Pero aún se puede avanzar un poco más. Cuando Oliveira pierde a la Maga se produce una búsqueda delirante de ella. Predominan los desvíos, las confusiones, la alucinación, incluso. El calificativo de la búsqueda, delirante, es importantísimo para nuestra tesis porque tiene complejas variaciones en las novelas en análisis. Para comenzar ¿no hay algo de delirante en toda la escritura de Rayuela? Si alguien pudiera dudarlo, en otra novela argentina, los Siete locos de Arlt, la ecuación escribir = delirar es absolutamente clara.

¿Y qué desata ese delirio tan extremado del personaje artliano que llega a "contaminar" al narrador? La respuesta parece evidente: la pérdida de Elsa, su mujer.

Puede argüirse que el carácter de "héroe demoníaco" o de "hombre apocalíptico" de Endorsain, conlleva en sí el delirio, pero parece claro que la partida, el abandono de su mujer, gatilla el proceso.

Pérdida de la mujer es otro enunciado clave para explicar el delirio que viene de las ninfas y el desvío, el giro súbito de la investigación del que hablamos. La noción de pérdida del ser amado nos conduce a una frase de Piglia: acerca de que el tema de la pérdida de la mujer desencadena el delirio filosófico en la novela rioplatense de vanguardia.

Esta extraña constante que muestra el relato vanguardista argentino le proporciona un nombre al delirio: filosófico. Nombre que reafirma la presencia de la figura inmemorial de la ninfa en estos textos. Primero, porque aunque Piglia no lo perciba, todas estas mujeres corresponden a la figura de la ninfa, como lo mostraremos, paradigmáticamente, en el caso de la Maga. Y segundo, porque el delirio que suscitan las ninfas es primordialmente filosófico o metafísico, si se quiere.

En La locura que viene de las ninfas y otros ensayos, Calasso lo muestra así: el "tomado", el "golpeado" o "raptado" por las ninfas se ve envuelto en el delirio filosófico. Sócrates lo evidencia, "el más célebre entre los nympholeptoi" (26). 
Horacio Oliveira, Borges (en tanto personaje del El aleph), Endorsain, son ninfoleptos, embargados por el "delirio filosófico".

Ninfolepto se llama al poseído por las ninfas, de donde resulta el delirio como una forma de posesión. Posesión, otra palabra clave y peligrosa en el orden de la Academia. La RAE, por ejemplo, define la posesión como "estado de la persona cuya voluntad se ve anulada por la influencia de un espíritu o demonio".

En las antípodas de esta definición sancionadora, la posesión entre los autores nombrados abre la puerta a una forma de conocimiento. ¿Qué le permite a Borges, el ninfolepto, acceder al conocimiento absoluto que le depara el aleph? El estar poseído por la ninfa Beatriz Viterbo $¿$ Y no sucede el mismo proceso con Oliveira en relación a la Maga o en Martín con relación a Alejandra, en Sobre héroes y tumbas?

La posesión muestra que la mente de estos personajes es un "lugar abierto a incursiones, invasiones súbitas, o provocadas", y que cada una de estas invasiones desencadena un "devenir". Devenir, en este caso, significa "hacer bloque" con el conocimiento elemental que portan las ninfas: no un conocimiento que quede fichado, catalogado en la mente, sino algo disponible como un algoritmo. O un aleph, juego de reglas simultáneas que solo pueden expresarse en un lenguaje matemático.

El devenir algoritmo del conocimiento se realiza mediante un agenciamiento con figuras que habitan al mismo tiempo la mente y el mundo. La Maga, Beatriz Viterbo y la Eterna son expresiones de esas figuras. Hay que abandonarse a ellas para lograr el conocimiento que reconocemos en la posesión. El abandono indica que la posesión puede ser expresada solo por términos eróticos. Como afirma Calasso, "el ser tomados por el dios y el ser golpeados por el dios son las dos modalidades fundamentales de la posesión que se corresponden a los dos modos de las epifanías eróticas de Zeus: el rapto y el estupro" (31). En este trabajo solo nos referiremos a una de las dos modalidades de epifanía, la del rapto.

Iniciamos la discusión citando una zona de La locura que viene de las ninfas:

"Si en el origen de la posesión encontramos una ninfa-Iynx-, si las ninfas proceden a la posesión en su máxima generalidad, es así porque ellas mismas son el elemento de la posesión, son esas aguas perennemente encrespadas y mudables donde de repente un simulacro se recorta soberano y subyuga a la mente. 
Y esto nos conduce al léxico griego: nymphe que significa tanto "doncella lista para la boda" como "fuente". Pero hay que preguntarse algo más sobre esas aguas, abrir su sello movible y una claridad imprevista nos vendrá de un fragmento de un himno a Apolo, citado por Porfirio, en el De antro nympharum. Allí se lee que Apolo recibió noeron udaton unas "aguas mentales". Aquí finalmente se nombra "the stuff nymphos are made of". Ninfa es entonces una materia mental que hace actuar y que sufre el encantamiento, algo muy afín a lo que los alquimistas llamarán prima materia y que aún resuena en Paracelso, donde habla de nymphidica natura" (34).

La lectura del párrafo ilumina súbitamente la condición de los personajes femeninos de los relatos de (pos) vanguardia aludidos: las mujeres son la materia mental que hace actuar y sufre el encantamiento.

¿Cómo entender esa condición de "materia mental" que hace actuar y sufre el encantamiento, de las ninfas ficcionalizadas en las novelas latinoamericanas que examinamos? Lo que atrae en la Maga y La Eterna es, precisamente, la renovada y renovadora relación que poseen con esa "prima materia", de la cual hablan los alquimistas. Relación conseguida mediante el rechazo del "metro mental de Apolo" (que ya explicaremos) y el abandono feliz a un modo de pensar desterritorializado y desterritorializante que escapa a las trampas con que el poder captura el saber.

En esta línea, "materia mental" hay que entenderla como fuerza posesiva que captura la mente y es capaz de producir los devenires en cuanto ella misma es un devenir.

En relación con este proceso, incursionando brevemente en el campo teórico, nunca nos quedó claro qué clase de fuerza produce los devenires en la teoría deleuziana. Sabemos ahora, aunque sea en un espacio restringido, que es la posesión de la mente por las ninfas la que produce esos eventos mentales que son los devenires. Lo anterior significa que, en el terreno novelesco en que nos movemos, no hay posesión sin devenir. No termina de extrañarnos que en Mil mesetas no figure la palabra posesión.

Volviendo al problema de la conexión entre las ninfas y el tema de investigación, otra frase de Calasso ayuda decisivamente a resolverlo: Apolo recibió de las ninfas el don de las "aguas mentales", pero ocultó de dónde venía ese saber que no le pertenecía: "Apolo fue el primer invasor y usurpador..." de "un saber líquido, fluido, al cual el dios le impondrá su metro" (14). 
Partiendo de esta afirmación, podemos "irreverentemente" establecer una conexión, que no figura ni podría figurar en las tesis de Calasso, entre panoptismo, fractura de éste y las ninfas. Es evidente que la novela panóptica trata de imponer su "metro" a ese saber fluido. No tolera la libertad de los flujos. Inventa una máquina disciplinaria para ocultarlos. Después de hacerlo los corta, los mide y los encierra. Encierra el saber del loco, de los niños, las mujeres y, ahora lo sabemos, de las ninfas. No tolera a los que transgreden el "metro".

La fractura, por el contrario, desmorona el "corte", el "encierro" y el "metro". Desoculta los saberes líquidos, fluidos. Saberes sometidos que expresan muy bien las ninfas. La ninfa Maga, la ninfa Beatriz, la ninfa Dulce Persona, la ninfa Alejandra.

Tal vez quien mejor represente esos saberes sometidos, más bien ocultados por la tiranía de Apolo, sea otra ninfa, Brígida, la protagonista de El árbol. Ella es sometida por "pueril", por "retrasada", por "niña chica". Términos despectivos producidos por el mundo masculino -el padre y el esposo-para conjurar algo que nunca podrán entender: el pensamiento de la alteridad.

De aquí que ahora debamos enfrentar la, paradójicamente, sombría figura del panóptico (que oculta la otredad y trata de someterla al modelo de lo mismo) con la figura "resplandeciente de signos" de la ninfa, materia mental que encanta, subyuga como el fluir de las aguas elementales, del pensamiento de la alteridad.

La investigación que continúa es un primer paso en el tema de las ninfas. Paso que, siguiendo a los trabajos mencionados, debe vencer una "hipótesis rudimentaria" -en términos de Calasso- la vinculación de las ninfas con el plano erótico.

Nos damos cuenta de que la "opinión común" tiende a creer en este vínculo. Pero las ninfas latinoamericanas que analizamos lo desmienten. Entre otras razones, porque casi no tienen cuerpo, dimensión en que asienta su reino el erotismo. Aparte de la "figura delgada", ¿hay otra mención en Rayuela al cuerpo de la Maga? Y qué sabemos del cuerpo de Beatriz Viterbo? Solo nos enteramos que la ninfa de El Aleph era "alta, frágil, muy ligeramente inclinada; había en su andar (si el oxímoron es tolerable) una graciosa torpeza, un principio de éxtasis" (188).

El escamoteo del cuerpo en Dulce Persona es total. Solamente Elsa aparece representada corpórea y sexualmente en las visiones atormentadas de Endorsain. Sin embargo, ellas resultan, a raíz de los hechos contados con posterioridad, alucinaciones morbosas dictadas por la desesperación. 
Otra cosa son las nínfulas, término propuesto por Nabokov en Lolita:

\begin{abstract}
"Ahora creo llegado el momento de presentar al lector algunas consideraciones de orden general. Entre los límites de los nueve años y los catorce años surgen doncellas que revelan a ciertos viajeros embrujados dos o más veces mayores que ellas, su verdadera naturaleza, no humana, sino nínfica (o sea demoníaca); propongo llamar "nínfulas" a esas criaturas elegidas" (24).
\end{abstract}

En las novelas de (pos)vanguardia latinoamericana encontramos, por lo menos, una nínfula: Araceli de Luna caliente, de Mempo Gardinelli. Esa joven de trece años corresponde plenamente al retrato trazado por Nabokov. Aunque la separan de Lolita rasgos dramáticamente distintos: la violación que sufre y la naturaleza indestructible que posee. (Quizás nos encontremos frente a una diferencia latinoamericana: la nínfula seductora, culpable de Nabokov, frente a la nínfula que se defiende y, que como toda la alteridad, a pesar de los esfuerzos por eliminarla, siempre reaparece. Araceli asoma entonces como paradigma político. Ejemplo de tal paradigma: los huesos de los desaparecidos).

Volviendo al carácter de las ninfas, ellas no están lejos de poseer un carácter perverso, además de ser muy dulces. De ahí que el conocimiento que deparan sea terrible porque es salvador y funesto a la vez. Luego, la relación con ellas es paradójica: poseerlas significa ser poseído. Y esta posesión puede desatar las fuerzas de la alteridad, fascinantes y mortales al mismo tiempo, como lo vemos en la Maga, en Elsa y en otras ninfas que no hemos nombrado: Remedios la Bella, la fascinante náyade de Cien años de soledad, Flora, la alseide, de Día Domingo y Estela, la agrónomo de Coronación.

En el "nombrar" la investigación se aproxima a la tarea de un arqueólogo: queremos desenterrar del nicho solitario de la Historia del Arte, en el que yacen las ninfas, sus figuras dulces, peligrosas y potentes, además de mostrar el conocimiento que ellas deparan.

Mas, las nombradas no son las ninfas que hablan griego, o las más encantadoras que prefería Darío porque hablaban francés ("unas cantan francés, otras son mudas"). Son las ninfas latinoamericanas, que escandalosamente, para algunos, aparecen desde la "primera" novela del Nuevo Mundo, Teresa o el terremoto de Lima, de Pablo de Olavide. El carácter de ninfa de la inquietante Teresa se fija en su vínculo con la tierra, como hemos mostrado en un artículo anterior: "Ella es símil del terremoto, como lo indica la "o" del título" (Rodríguez y Rodríguez 302). Postulamos entonces que desde el libro 
de Olavide las ninfas no han dejado de ser ficcionalizadas, hasta hoy, en la novela latinoamericana. Baste pensar en las hermanas Font de Los detectives salvajes, hésperides o ninfas del jardín.

Las ninfas latinoamericanas, sostenemos además, no guardan ninguna "devoción excesiva" a los modelos grecolatinos. Recordemos, con Borges, que los sudamericanos "podemos manejar todos los temas europeos, manejarlos sin supersticiones, con una irreverencia que puede tener, y ya tiene, consecuencias afortunadas" (273).

Entre las consecuencias afortunadas podríamos citar la parodia de la ninfa canónica efectuada por José Donoso en dos textos: la travesti Manuela, del Lugar sin límites y la tierna nínfula Ana María, del cuento homónimo, que solo tiene tres años.

Finalizamos el preámbulo con una cita del cuento La ninfa de Rubén Darío, que fija y consagra espléndidamente el arquetipo griego:

"Estaba en el centro del estanque, entre la inquietud de los cisnes espantados, una ninfa, una verdadera ninfa, que hundía su carne de rosa en el agua cristalina: la cadera a flor de la espuma parecía a veces como dorada por la luz opaca que alcanzaba a llegar por las brechas de las hojas. ¡Ah! Yo vi lirios, rosas, nieve, oro; vi un ideal con vida y forma y oí, entre el burbujeo sonoro de la linfa herida, como una risa burlesca y armoniosa que me encendía la sangre" (119).

Más allá de la belleza, para no caer en la "hipótesis rudimentaria", interesa destacar lo que ve el poeta gracias a la ninfa: "lirios, rosas... un ideal con vida y forma". Es decir, el poeta accede a una forma de conocimiento. Conocimiento radicalmente distinto al saber masculino que reina en Occidente, como la misma Lesbia, la ninfa del cuento, lo confirma: "Basta de sabiduría - dijo Lesbia- y acabó de beber la menta". Anotamos que Darío sabe del asunto, pues la planta de la menta es producto de la metamorfosis de la ninfa Mente.

Si alguien se tomara el trabajo de preguntarnos ¿pero qué significan al fin todos estos regodeos, en su sentido estricto de complacencia, con las ninfas? La respuesta justa y exacta podría causar estupor.

Tal vez el temor, este temor de escandalizar, de decirlo todo de golpe, justifique la introducción realizada al tema de las ninfas. La introducción actúa como preámbulo, como una preparación para ir asentando una verdad inconveniente. Política, estética y éticamente inconveniente: ¿O no lo es 
afirmar que un pensamiento revolucionariamente nuevo, conjugado con la plenitud de la utopía es el rasgo básico del pensamiento nínfico?

La Maga, si la observamos con esta nueva mirada, es primordialmente la utopía de la libertad que se opone a la anti-utopía disciplinaria del panóptico. Dulce Persona es la realización de la utopía máxima: matar la muerte.

La Maga, Dulce Persona, Alejandra, La Bella Remedios, etc. no son heroínas heroicas que vienen a hacer la revolución política. Lo que ellas portan son las semillas de una moral, de una estética revolucionaria que parte por desocultar un "saber enterrado". Incluir lo otro, y matar el odio, matar la violencia, matar la muerte para devenir todos Dulce Persona. Tal vez esa sea la utopía pensada por las ninfas latinoamericanas: una sociedad de Dulces Personas.

\section{II}

\section{EL PANOPTISMO Y SU FRACTURA}

La anti-utopía de una sociedad disciplinada, purificada, atravesada por toda una jerarquía y expuesta desnuda al ojo vigilante del poder que representa la novela realista latinoamericana, se desmorona estrepitosamente con la novela (pos)vanguardista que postula otra realidad heterogénea, impura, desjerarquizada e incontrolable. Las dos modalidades de representación colocan en nuestra escena narrativa dos tipos de novela: la panóptica, ya analizada por nosotros (Rodríguez y Triviños), y aquella donde se fractura ${ }^{2}$ el espacio panóptico, que trataremos ahora de explicar.

Los relatos de la fractura proponen otra utopía: abandonarse a ese "sueño voluntario", sueño que permite, según Borges, manejar todos los textos y discursos sin supersticiones y con irreverencia, abandonarse también a ese "libertinaje literario" ya mencionado y sin dejar fuera de ningún modo la idea de la literatura como "robo", "traición", "moneda falsa", ficcionalizada por Piglia en Nombre falso.

2 Usamos el término "fractura" intencionadamente, pues el panóptico es un modelo de estructura arquitectónica. 
Sueño voluntario, libertinaje, robo, traición desplazan-como dijimos-en el nivel del narrador, la figura del gran vigilante e instalan la contrafigura del "traidor", a cuya caracterización inicial añadimos, ahora, la simulación y el engaño que contribuyen a la imposibilidad de discernir la veracidad de lo que está en juego. Tal como sucede en Los siete locos de Arlt.

La propuesta que sigue contiene inevitablemente reiteraciones de lo ya afirmado en el preámbulo.

En algún modo, tales reiteraciones son una suerte de convencer, y autoconvencerse, de la presencia de las ninfas en la novela de Latinoamérica, existencia que parecía reservada, hasta ahora, solo a los cuentos y poemas de Rubén Darío. (Auto)convencer, también, que lo otro en toda su potencia se expresa en el pensamiento desatado -el delirio filosófico- por las ninfas. Y que escribir, en este contexto, significa estar poseído por ellas. Proceso en que el término posesión no se vincula con un referente enfermizo, patológico o incluso satánico, sino con el estar "raptado" por un tipo de conocimiento otro, por un delirio, por una fuga hacia la alteridad.

El término posesión es, en realidad, muy complejo. Uno de los problemas que éste plantea se marca en que la sola presencia de las ninfas no desata de por sí el delirio. Para delirar es necesario estar capturado, raptado, por las ninfas. En muchos relatos, el personaje masculino no se deja atrapar. Él se aferra a las normas convencionales, como es el caso de Luis, el marido -padre de Brígida en El árbol de Bombal. En otros, se establece un vínculo puramente erótico con la ninfa, en que deslumbra su belleza, como sucede con los admiradores trastornados de Remedios la Bella en Cien años de soledad, lo que los incapacita para acceder a ese otro modo de pensar que la joven, estancada en una "adolescencia magnífica, cada vez más impermeable a los formalismos, más indiferente a la malicia y a la suspicacia”, prodiga con una inocencia perturbadora.

No examinamos a los personajes que no se dejan perturbar. Algunos de ellos pertenecen en propiedad a la novela panóptica, otros simplemente no entran, no se inician, en el delirio filosófico que provocan las ninfas.

El delirio precipita al narrador y a sus personajes por encima o por debajo (esto último más que lo primero) de la línea que postula la racionalidad de lo real y la veracidad del lenguaje.

El delirio en la escritura, o la escritura delirante, la entendemos como "una forma no alucinatoria con conservación de la integridad mental del sujeto" (Deleueze, Crítica 126). 
Lo que hacen las novelas de vanguardia que examinamos es entregarse abiertamente al delirio, constituirse en él. Ese delirio que arrastra al narrador (y a los personajes) en las novelas de Arlt lo conduce llamativamente a identificar la literatura con el crimen, la estafa y la falsificación. Por su parte, solo un narrador delirante como el de El Museo de la novela de Eterna, puede atreverse a postergar una y otra vez el inicio del relato, escribiendo cincuenta y nueve prólogos. Delirio de postergación. El delirio mental es el que permite a Borges, personaje de El aleph, encontrar esa esfera maravillosa y ver simultáneamente toda la creación en ella. Delirio del ojo.

Podemos multiplicar los ejemplos, pero lo que nos interesa en este punto es aclarar que las referencias al delirio paranoico y subjetivo pasional, que hemos hecho siguiendo a Deleuze, no pretenden psicoanalizar al narrador y a sus personajes. Lo que nos interesa al atraer al nivel crítico el tema de los dos tipos de delirio, especialmente el pasional, es la idea de que la narración delirante es antilineal. En ella, escenas que vienen de muy lejos y de muy abajo resuenan de pronto en la superficie del relato, como lo muestra Piglia a propósito de Joyce en Las formas breves. Este modo narrativo, que va contra la lógica de la construcción del relato realista, al avanzar mediante asociaciones inesperadas, evocaciones oníricas, es un rasgo importante de lo que llamamos fractura del panoptismo. Lo vemos funcionando como una "máquina polifacética" en Los siete locos y en Los lanzallamas, de Roberto Arlt. Al hablar de "máquina polifacética", queremos decir que ella descompone de manera violenta la máquina realista panóptica de contar. Así, por ejemplo, avanzada la novela Los siete locos aparece inesperadamente, a través de la nota 1, la figura de un "comentador". La nota expresa: "Este capítulo de las confesiones de Endorsain me hizo pensar más tarde si la idea del crimen a cometer no existiría en él en una forma subconsciente, lo que explicaría su pasividad frente a la agresión de Barsut" (68).

La situación de esta figura del comentador es azaz ambigua. La nota a pie de página pretende establecer una distancia objetiva entre los hechos narrados y quien los comenta. Sin embargo, el contenido de la acotación implica una total participación del comentador en los sucesos narrados. Ella se expresa a través de una idea, una interpretación razonada de la actitud inexplicable del personaje Endorsain ¿No corresponde esta actitud a la figura racionalizadora del narrador panóptico? Pareciera serlo, aunque falta un rasgo esencial de esa figura: el juicio moral sobre el hecho narrado. Recordemos que se está tramando un crimen y el comentador habla de ello razonadamente, con toda 
naturalidad, como si fuera un acontecimiento que no contraviniera ninguna norma ética.

Por lo anterior, hemos propuesto añadir a los rasgos que contribuyen a desplazar la figura del narrador panóptico en las novelas de vanguardia, la supresión del juicio moral. Al hablar de "juicio moral" no pensamos que su suspensión equivale a la falta de una mirada ética en el relato vanguardista. Al contrario, es indudable que "la moral panóptica" es una adecuación a los fines del poder que opera en sus relatos: la consecución de cuerpos dóciles y productivos. La inexistencia de este tipo de moral en las novelas que abandonan la omnisciencia-omnipotencia del narrador implica una resistencia y un rechazo a tales prácticas sociales represoras de la libertad y de la realización autónoma del sujeto.

La "máquina polifacética" contiene una moral que desplaza a la que opera en las novelas panópticas, que funcionan en una sola fase: la controlada por el poder. Se enfrentan, de este modo, una ética fundada en lo heterogéneo, que acepta la diversidad, con otra intolerante, fundada en la pura homogeneidad.

La "máquina polifacética" sería el resultado de otra forma de delirio, no alucinatorio, que embarga al narrador de la vanguardia. El delirio erosiona lo homogéneo, arrastrando partículas inesperadas, desplazando los roles narrativos canónicos (narrador, lector) para inventar nuevos. Es un flujo irreprimible de la imaginación.

En los relatos de vanguardia que deseamos examinar, de Cortázar, Borges, Macedonio, Arlt, Giardinelli, hay diversas formas de delirio. Nos proponemos analizar una de ellas, la apuntada por Piglia tanto en Crítica y ficción como en Formas breves. Esta plantea esa constante curiosa en la novela argentina: "en los relatos de Macedonio, como los de Borges, Marechal Cortázar, Arlt (agregamos a Sábato) "la pérdida de la mujer -llámese la Eterna, Beatriz, Solveig, La Maga, Elsa (Alejandra)- desencadena el delirio filosófico" (Piglia, Formas 35).

En el texto ya mencionado, La locura que viene de las ninfas y otros ensayos, Roberto Calasso escribe, como sabemos, sobre el mismo delirio, pero ahora desencadenado por las ninfas. Él examina ese estado mental que nos excede y nos transporta originado por las ninfas.

Dicho examen nos conduce ante la presencia de un fenómeno inquietante, explorado por el crítico italiano a través de una interrogación: 
¿Qué son las ninfas, se pregunta? Él comienza diciendo que a partir de su origen representan el fenómeno de la posesión, y afirma que en realidad ellas mismas son el fenómeno de la posesión, "son esas aguas perennemente encrespadas y mudables donde de repente un simulacro se recorta soberanamente y subyuga la mente" (34).

Creemos que las ninfas representan esa potencia y dentro de ella un "devenir loco de lo ilusorio". Subversivo además, porque el simulacro incluye en sí la mirada del observador que lo transforma y deforma para esquivar lo semejante. Se puede decir que las ninfas, en tanto potentes simulacros, son la "materia mental" que hace actuar y provoca el delirio. En los relatos sobre ninfas, estudiados por el autor, se afirma que quien vea una aparición emerger de una fuente, es decir, una ninfa, delira: "El delirio suscitado por las ninfas nace entonces del agua y de un cuerpo que emerge de ella, así como la imagen mental aflora del continuo de la mente" (35)

El tomado por las ninfas, como ya sabemos, se llama ninfolepto (nympholeptoi). Uno célebre-dijimos- es Sócrates. En el Fedro no olvida dirigir una plegaria a las ninfas, después de admitir que se sentía ninfolepto, alguien raptado por las ninfas. En el mismo diálogo, Sócrates habla del delirio producido por las ninfas y cómo a través de este "justo delirar" se puede alcanzar la liberación de los males.

No podemos decir enfáticamente, volviendo a las mujeres que desencadenan el delirio en las novelas latinoamericanas que examinamos, que haya en su representación una "supervivencia de lo clásico"; pero sí podríamos admitir que en tanto figuras femeninas clave de las novelas elegidas, puede existir en su configuración esa presencia de lo sagrado, que se produce cuando lo femenino se enlaza con el origen, envolviéndose la vida en los ropajes del mito. Tal condición primigenia se expresa en ese flujo molecular de "saberes sometidos" y ancestrales que ellas portan.

El mito de la ninfa lo vemos en una figura emblemática de la novela latinoamericana: la Maga. Desde el comienzo de Rayuela, ella es representada como ninfa:

“¿Encontraría a la Maga? Tantas veces me había bastado asomarme, viviendo por la rue de Seine, al arco que da al Quai de Conti y apenas la luz de ceniza y olivo que flota sobre el río me dejaba distinguir las formas, ya su silueta delgada se inscribía en el Pont des Arts, a veces andando de un lado a otro, a veces detenida en el pretil de hierro, inclinada sobre el agua" (20). 
La relación fundamental, el agenciamiento, que tienden a hacer las ninfasnáyades con el agua está visiblemente retratada en el texto. El Sena, con su luz de ceniza y olivo, sus puentes, es el territorio natural de la Maga. Solo hay una diferencia. Diferencia que la hace simulacro de la ninfa griega: ella no surge del agua, se inclina sobre las ondas.

A pesar de la diferencia la reterritorialización líquida, fluyente, de la Maga, nos entrega una visión estupenda: la Maga - ninfa, la Maga - náyade.

La Maga-náyade es esa "materia mental" que se mueve como las aguas "encrespadas y mudables", rompiendo los "diques del orden" dictado por el logos, para asumir un devenir ilimitado (también deviene golondrina) donde "lo más y lo menos van siempre de adelante", esquivando suavemente lo igual, el límite, lo mismo o lo semejante. Dulce náyade del Sena, la Maga, como lo ha llegado a entender Horacio, nada los ríos metafísicos:

"Ella los nada como esa golondrina está nadando en el aire, girando alucinada en torno al campanario... Yo describo y defino y deseo esos ríos, ella los nada. Yo los busco, los encuentro, los miro desde el puente, ella los nada. Y no lo sabe, igualita a la golondrina" (120).

La diferencia marcada entre "salir del agua", como movimiento canónico de la ninfa, y "estar inclinada sobre el agua", como gesto de ruptura de la tradición se puede resolver del siguiente modo: la golondrina al nadar en el aire lo transforma en un río, lo que permite asegurar que cielo y río se confunden formando otra entidad que se llama "río metafísico". Lo que hace la Maga, en realidad, es recostarse sobre el río del cielo. Una náyade que emerge de las aguas turbulentas del cielo.

Las ninfas latinoamericanas, en este primer nivel de interpretación, nadan los ríos y los cielos de la otredad. Y lo hacen sin saberlo. Una realidad deseada que Apolo ocultó y mintió sobre ella. Sabemos que este Dios, en el mito griego, estableció relaciones tortuosas de atracción y persecución mortal de las ninfas. Siempre quiso destronar sus poderes y borrar todo vestigio de un conocimiento distinto y trasgresor. Para conseguir lo último, impuso otro modo de saber, el apolíneo, sepultando lo que no le convenía.

De un modo casi fantástico, maravillosamente inesperado -a menos que creamos en la pervivencia perenne del mito-el saber no apolíneo de las ninfas reaparece en el delirio que suscitan las mujeres perdidas por el héroe de las novelas latinoamericanas de vanguardia y posvanguardia. Las ninfas Maga, Eterna, Solveig, Beatriz, etc., al romper el "metro" impuesto por el dios, para 
el caso el dios del relato, desencadenan en los narradores un delirio pasional que los precipita a una búsqueda sin término de esos saberes sometidos.

¿Encontraría a la Maga?, se pregunta Horacio Oliveira al comienzo de Rayuela. Preguntar por la Maga equivale a interrogarse por una "llave", "un puente", un "hueco" que permita franquear el abismo, dar el salto hacia el otro lado, en busca de ese saber que "no sabe", pero entiende todo.

El delirio pasional en que se embarca el narrador, comentador y personaje en Los siete locos, después de la pérdida de Elsa, es desquiciador, terrible y mortal. Mortal, porque conduce a un crimen. Endorsain, después de que su esposa se va con un desconocido, siente que:
"ya no era un hombre, sino una llaga cubierta de piel, que se pasmaba y gritaba a cada latido de sus venas. Vivía simultáneamente en el alejamiento y en la espantosa proximidad de su cuerpo. Él ya no era un organismo envasando sufrimiento, sino algo más inhumano... quizás eso... un monstruo enroscado en sí mismo, en el negro vientre de la pieza" (58).

El espantoso delirio desencadena una vía de pasaje mortal: el personaje deviene monstruo alojado metafóricamente en el vientre terrible de la muerte. El devenir feto monstruoso, empozado en las tinieblas, precipita a Endorsain, una vez recobrada penosamente la conciencia, a la idea obsesiva de que para vivir tranquilo es necesario asesinar a un hombre. En este caso a Barsut. Este es un personaje que llega a visitarlo después de la partida de Elsa, que le reprocha no haber sido "lo suficientemente hombre" para retenerla. Barsut es otro "hombre de la inequidad" que circula por el relato, aunque sin la capacidad de humillación que lleva a Endorsain a las mayores abyecciones. De lo que carece Barsut es de esa cualidad que tiene el esposo de Elsa: desencadenar la función positiva de la negación que caracteriza al llamado héroe apocalíptico.

El asesinato se presenta como una manera "de ser a través de un crimen". "Yo que soy la nada, de pronto pondré en movimiento ese terrible mecanismo de polizontes, secretarias, periodistas, abogados, fiscales, guardacárceles, coches celulares, y nadie verá en mí a un desdichado sino al hombre antisocial, el enemigo que hay que separar de la sociedad; ¡Eso sí que es curioso! Y sin embargo, solo el crimen 
puede afirmar mi existencia, como el mal afirma la presencia del hombre sobre la tierra" $(73)^{3}$.

El crimen es una forma de vencer la inercia de la nada y producir un movimiento que aunque negativo, culmina en la positividad de ser. De ser a través de la negación. Existir como negación. Son las huellas del crimen las que nos permiten dar señales de vida en la tierra ${ }^{4}$.

Michaux, recuerda Baudrillard, piensa que "el artista es aquel que se resiste con todas sus fuerzas a la pulsión fundamental de no dejar huellas" (11). El héroe de Arlt, por el contrario, se empeña a fondo por dejar los más evidentes rastros de su crimen.

El crimen en Los siete locos es, ante todo, una forma de comunicación con el otro, una premonición de la alteridad: "Y sin embargo, yo el asesino, he amado a todas las bellezas y he luchado en mí mismo contra todas las terribles tentaciones que hora tras hora subían de mis entrañas. He sufrido por mí y por los otros ¿se da cuenta? También por los otros" (99).

Confesión estremecedora: sufrir por los otros. Se sustrae al asesinato de la esfera cerrada (y alterada) de la pura subjetividad para proyectarlo a una colectividad sufriente que se agita y lucha. El crimen ya no es un acto atroz que atañe a un solo individuo. Afecta a una comunidad entera que necesita dar señales de existencia sobre la tierra. El crimen se transforma en un acto político.

Pero también el crimen cometido por Endorsain es más que una huella, es un aullido por el dolor y sufrimiento de todos. Contribuye a su terrible imperfección que la víctima no sea al final Barsut, sino una niña indefensa, la Bizca, que ama a Endorsain.

El crimen en Roberto Arlt no está cifrado en el asesino y en la víctima, que al final importan poco, sino en su carácter de grito desgarrado de una humanidad sufriente, humillada, pisoteada por su propio creador, Dios. Una humanidad dispuesta a castigar al padre que la desconoce. Una humanidad

3 El crimen pone en movimiento "un terrible mecanismo" que no es otro que el mecanismo panóptico. Cuestión que pone en juego las complejas relaciones entre panoptismo, fractura, delirio y narración.

4 Tema ampliamente desarrollado en otros autores, ya no latinoamericanos, como Bukoswki. Un ejemplo, lo encontramos en Decadencia y caida, donde leemos "el crimen hace sentir vivir" (32). 
que deja crecer en su seno el mal. Cometer un crimen es rebelarse ante la humillación que practica Dios contra su pueblo. Es una suerte de ascesis del mal para buscar una pálida felicidad que destella tenuemente a lo lejos. Transgresoramente a través del crimen se quiere inventar ese pueblo que falta, del cual habla Deleuze.

Quien representa esta forma de trasgresión en las novelas de Arlt, y lo hace de un modo fulminante, es el Astrólogo. El personaje "puede ser pensado como un gran criminal que formula la idea del crimen personal y colectivo como una fábula chirrigueresca de dominación" (González 137). El Astrólogo propone una concepción sacrificial de la historia: es necesario matar a muchos para edificar un mundo glorioso. Asesinar a la humanidad para alcanzar su redención. El carácter sacrificial se enlaza con el mesiánico. Cree el Astrólogo que "los dioses provocarán cataclismos espantosos, distribuirán las pestes fulminantes", contribuyendo a la violencia redentora propiciada por los personajes artlianos. Hay tal exceso en la propuesta del Astrólogo, que ella se transforma en una caricatura funambulesca del totalitarismo político. Funambulesco en su sentido estricto: como algo extravagante, exagerado, grotesco, llamativo.

A pesar de todo, el héroe de la iniquidad, el héroe apocalíptico, Endorsain, ama la vida: "Y de pronto un grito estalla involuntariamente, en Endorsain: Pero yo te amo vida, te amo a pesar de todo lo que afean los hombres. Sonríe en la oscuridad y se queda dormido" (220). Último enunciado pleno de significaciones: "sonríe en la oscuridad", revela que fracturar el panóptico implica valorar los lugares oscuros, lugares que el Ojo Vigilante rechaza, porque es ahí donde se pueden producir las mezclas de flujos, de razas, de sexos. De ahí la obsesión del vigilante por iluminar hasta el último rincón. Contrariando esta obsesión, la oscuridad es ahora un lugar de paz. Por ello el personaje que alcanza realmente un nuevo tipo de conocimiento en el texto es Endorsaín. Un conocimiento criminal que, junto con transgredir una moral fundada en el temor al poder divino y humano, propone otra fundada en el amor a la vida. Este "justo delirar" permite alcanzar la liberación de los males de la que hablaba Sócrates.

Siguiendo la misma línea anterior, postulamos que no hay mayor delirio, ni mujer más compleja que lo suscite, que el narrado en Museo de la novela de la Eterna.

La muerte de la Eterna produce en el narrador, que se confunde a veces con el personaje del Presidente, un delirio extraordinario: el de la escritura concebida, ya no como la resistencia, sino como la expulsión de la muerte: 
"La novela debe desarrollarse en un clima sin disturbios, reyertas, celos, aunque existan las tristezas de la vida, como agrupamiento intercausal directo e inspeccional" (65).

Vivientes que no se dibujan ni describen, cosas que no hay; juego con la muerte que ocurre y nunca mata, donde todo vuelve de la muerte. Los personajes mil veces vueltos de la muerte; de automuerte por mero deseo, sin veneno ni puñal; que tienen a la muerte por un dormir sin horario, no nocturno: "la muerte no es la policialidad que conocemos, sino una mesa eternamente concurrida y de la que se levanta uno y dice: yo me voy a dormir; eso es la muerte" (225).

Las estrategias textuales desarrolladas en el párrafo tienen un solo fin: rescatar a la Eterna de la muerte. Por lo demás, esa es la finalidad que propone toda la novela. Y ello es de suyo relevante para nuestro propio delirio crítico, provocado por las ninfas, pues el relato, en este sentido, no es sino la reelaboración del mito del origen de la literatura, el descenso de Orfeo al reino de la muerte en busca de la ninfa Eurídece.

Vivientes que no se describen, cosas que no hay, apuntan a esa "novela sin mundo" que persigue Macedonio. Se postula una desterritorialización de lo real, "una expulsión de la presentación geométrica y física de las cosas" para sentir el vacío del mundo que posibilita "el ser esencial, sin pluralidad" (44).

Para el delirio filosófico de Macedonio es "equivocado" creer en la existencia del mundo externo, porque todo es psique, y la psique es inmortal.

Esta "psique inextensa" no tiene posición en cuerpos, ni límite para manifestarse en múltiples cuerpos. "En suma: que nada cambie por la muerte si tenemos anhelo de que no cambie como único anhelo" (53).

En el mundo vacío de representación, creado por el delirio de Macedonio, se puede jugar con esta muerte que no mata y, por consiguiente, no cambia nada. No hay cuerpo para que ella ejerza ese fatal mandato. Y si lo llegase a haber, la supresión de la visibilidad de la persona no podría ser sino un ocultamiento momentáneo.

La muerte de Elena, la esposa real de Macedonio, ficcionalizada en la novela por las figuras de Dulce Persona y la Eterna, es solo un ocultamiento. Ocultación, de todos modos, terriblemente dolorosa porque "lo más que tiene es el silencio de noticias del sentir de la persona ocultada, el imposible de saber y socorrer su dolor actual, o de compartir la felicidad actual de la figura ocultada. Lo que no tiene la muerte es: muerte" (54). 
Para tener noticias de la amada y compartir con ella es necesario matar el ocultamiento que produce la muerte. Matar la muerte: "Yo todo lo voy diciendo para matar la muerte en Ella" (53).

Fascinante delirio metafísico, filosófico, que desencadena la pérdida de la mujer: escribir ("decirlo todo") para matar la muerte.

La novela de la Eterna tendrá así una función sagrada: "ser el Dónde a que descenderá la Amada volviendo de una muerte que no le fue superior"... "no resucitada sino renacida, sonriente como partió y con apenas un solo ayer de su ausencia de años" (55).

Macedonio (autor), el Presidente (narrador - personaje) han sido poseídos por la ninfa Elena -Dulce Persona- la Eterna. La posesión desata un delirio creador: transformar la novela en un espacio mágico de vida capaz de albergar a la ninfa superior a la muerte. La potencia de la ninfa Dulce Persona (Elena y la Eterna) transforma la novela en un ámbito de vida, expulsa la muerte y "regala" un conocimiento. Conocimiento que Calasso llama "metamórfico", en cuanto "cada metamorfosis es una adquisición de conocimiento" (31).

Nosotros preferimos -como establecimos en el preámbulo- la palabra devenir para expresar el proceso de adquisición y "de regalo". Justificamos la preferencia en lo ya dicho y porque, además, nos conecta con una idea revolucionaria y maestra de Macedonio. Como se afirma en el capítulo "novela en la novela": "los personajes de esta novela, pues, carecen de cuerpo físico, de órganos, de sentido, de cosmos" (224).

Como si fuera un "pase mágico", el enunciado nos conecta con las tesis de Deleuze sobre el "Cuerpo sin Órganos". Los personajes devienen intensidades que hacen pasar los flujos delirantes. Personajes, incluso, desligados de todo cosmos", ya que la novela "tiende a disolver la supuesta causación del cosmos sobre la conciencia" (224). Grado cero de los personajes.

Bellamente, el texto explica esta situación: "sin tigres nos sentimos heridos y ahorcados por un tigre" (53). Observamos que la supuesta lógica de la causalidad se "transforma" deviene, pura intensidad capaz de hacer sentir los efectos de la herida sin que exista la causa.

Personajes grado cero son entre otros: Suicida ${ }_{2}$ "muere a cada instante por su propia mano" (27); Bellamuerte, "la por haber más amor ida, por exaltar el amor" (29); Volupta: "aspira a un beso de un año y morir" (24); Mimosa: "odia lo privado de mimosidad" (34); Retroante: "cambia los pasados. Alguien le pide que le torne un pasado feliz"; Eterna: "no conoce la muerte" (30).

En cierto modo, lo narrado en Museo de la novela de la Eterna es un pensamiento delirante, un delirio filosófico producido por la pérdida de la Eterna. 
La posibilidad de que la novela sea la narración de un pensamiento es propuesta por Piglia, a través de Tardewski, un personaje de Respiración artificial, quien sostiene que Valery habría afirmado que "El discurso del método es la primera novela moderna" (179). Luego, se puede entender que El discurso del método narra un pensamiento, una idea como si fuera un asunto novelesco.

Hay una diferencia en lo propuesto por Piglia y en lo realizado por Macedonio. Si en la "novela" de Descartes el cogito es narrado con la lógica de una construcción policial, según anota el mismo Tardewski: "En el fondo, visto así, se podría decir que Descartes escribió una novela policial" (179); en la "novela" de Macedonio se narra anticartesianamente "tomado", "raptado", "golpeado" por la pena y el deseo que produce la Eterna. La Eterna que muestra maravillosamente su carácter de ninfa en la figura de Dulce - Persona: "De cuantos son hoy en la "novela" todos ya estaban cuando el inesperado tan placentero para todos, arribo de la Dulce - Persona-bautizada así por ellos luego, y único habitante que hubo allí- y lo gracioso de que desde la ciudad trajera flores en la mano para el Presidente, caminando así a través de un jardín" (141).

El "bloque", "agenciamiento" o simplemente la vinculación con las flores y el jardín hacen de Dulce Persona una alseide o ninfa de las flores. Pero también ella es una náyade, ninfa de las aguas, según se describe en el párrafo siguiente: "Quizagenio fue quien tuvo la sorpresa de abrirle la puerta. El día era algo frío, nebuloso, se divisaban las aguas del Plata palpitando sobre la línea de la ribera y agitarse la arboleda que lo bordea frente a la estancia" (142).

¿Cómo negar la presencia de la ninfa en este relato? ¿Cómo no maravillarnos con su presencia? Después de leer los 59 prólogos y el capítulo II de la novela que los sigue, sucede algo estupendo: la aparición de una ninfa.

Mencionarlas, convocarlas, dibujarlas en el entramado de esta investigación crítica sobre la novela latinoamericana parece un juego agradable, tal vez dotado con un cierto encanto, pero totalmente intrascendente, artificioso, por añadidura. Consecuentemente, pareciera no tener ninguna relación con la realidad histórica cultural de esta parte del mundo.

Ello no es cierto. Primero, y ya lo dijimos: nosotros no inventamos la presencia de las ninfas en estas novelas. Ellas están ahí.

En segundo lugar damos una información fascinante: no estamos, precisamente, trasladando modelos griegos a nuestras tierras, pues el de las ninfas es un mito extendido. Así, por ejemplo, las mujeres de los árboles no se llaman 
dríaes en la sierra colombiana, sino atiseinekum; las diosas de los bosques, las griegas hamandríades, en el Chaco son las wöro y las náyades, ninfas de agua dulce, muestran similares atributos a las champallu (o zampayu), deidades que se bañan desnudas en las aguas del río Cautín.

$\mathrm{Y}$ en tercer lugar es necesario considerar, "que el conocimiento metamórfico es un río subterráneo que aparece a la luz y desaparece de nuevo por toda nuestra historia" (Calasso 31). Conocimiento que en las novelas latinoamericanas expresa un tipo de saber que se emparenta con la posesión y el delirio.

Hoy en día, cuando el deseo, la pena o la ira asaltan la mente del sujeto y se hacen excesivos $y$, por ende, lo hacen actuar de forma extraña, afirmamos que es víctima de una enfermedad. La constatación permite emprender la curación del sujeto para devolverlo a la normalidad. Mecanismo panóptico por excelencia.

Los griegos, y también los chamanes, creían, por el contrario, que las divinidades hacían actuar así. Que estaban poseídos por un dios. En el origen de la posesión que narran las novelas estudiadas, siempre encontramos una ninfa. De ahí resulta que las ninfas mismas son el elemento de la posesión. Subyugan la mente y desatan el delirio filosófico envuelto en devenires desterritorializantes.

La desterritorialización permite que ellas, las ninfas latinoamericanas, se muevan dentro de una ética, una erótica, una estética, capaces de resistir el control panóptico, las disciplinas burguesas y la moral que fabrica el poder. De ahí que en Latinoamérica las ninfas ficcionalizadas en los relatos analizados sean portadoras de la utopía que hemos descrito.

Por último, el pensamiento de las ninfas es un pensamiento que se encuentra muy cerca de la música, capaz de oír los bloques de infancia y de feminidad que la atraviesan, como, precisamente, oye la dríade Brígida de El árbol:

"Mozart, tal vez -piensa Brígida. Como de costumbre se ha olvidado de pedir el programa- Mozart, tal vez, o Scarlatti... Qué agradable ser ignorante ¡No saber exactamente quién fue Mozart, desconocer sus orígenes, sus influencias, las particularidades de su técnica! Dejarse llevar solamente por él, como ahora... Y Mozart la lleva en efecto. La lleva por un puente suspendido sobre un agua cristalina que corre en un lecho de arena rosada. Ella está vestida de blanco, con un quitasol de encaje, complicado y fino... Altos surtidores en 
que el agua canta... sus dieciocho años, sus trenzas castañas que desatadas le llegaban hasta los tobillos" (208).

Brígida nos ayuda a entender que la expresión musical es inseparable de un devenir-mujer, de un devenir-niña, de un devenir-pájaro. Nos revela también, que son estos devenires los que constituyen el contenido de la música para Brígida ¿Qué significa esto? Que la música es atravesada por todas las minorías posibles, entre ellos el devenir ninfa.

Aquí no importa como cantan o tocan las ninfas, si es que lo hacen. Por lo demás, la Maga canta espantosamente. Lo que vale, sin duda, es que el pensamiento de la Maga, de Brígida, etc., deviene pensamiento musical. Ritornelos de mujeres que desterritorializan las líneas duras y compactas de los dispositivos del poder, franquean umbrales para encontrar las utopías ${ }^{5}$ y de ellas una siempre negada: "nada más que ser feliz" (Fernández, El museo 64).

La felicidad en las ninfas está conectada a la "ignorancia" como en el caso de Brígida. Ella escucha a Mozart fuera de las normas canónicas. No sabe nada del compositor, incluso no está segura que la pieza que tocan sea de él. Sin embargo, "que agradable es ser ignorante; ¡No saber exactamente quién fue Mozart!; desconocer su orígenes, sus influencias, las particularidades de su técnica! Dejarse solamente llevar por él de la mano, como ahora" (208).

La felicidad proviene de un saber no organizado metro a metro, centímetro a centímetro, como lo exige el poder panóptico ("el metro del dios Apolo"). No saber por ejemplo, que Mozart, apunta Deleuze, fue uno de los primeros que "sexualizó las voces en la música instrumental y orquestal, restaurando la máquina binaria en la que la voz de un hombre sea siempre la de un hombre y la de una mujer sea la de una mujer (Deleuze, Mil 305). No decimos esto por pedantería, sino para explicar el "pensamiento metamórfico", es decir, un devenir menor, producido por la "ignorancia" de Brígida.

Este devenir de la driade de Bombal consiste en que ella feminiza a Mozart, sin saberlo, naturalmente. Es su modo ignorante de escuchar que feminiza el mundo y dentro de él, la música. Mozart la lleva de vuelta al jardín

5 Quizás una conexión más concreta se sitúa en el hecho de que las utopías tienen la capacidad de movilizar el pensamiento y, con él, la historia. Al igual que las ninfas movilizan el pensamiento y, con él, la escritura. 
de sus años juveniles y de vuelta a una frase de su esposo: "eres un collar de pájaros -le decía Luís- eres como un collar de pájaros” (209).

Pensamiento musical que vuela, recorre girando el cielo sobre el jardín, va y vuelve caprichosa y bellamente como un collar de pájaros. Como toda línea de fuga o desterritorialización creadora este pensamiento conlleva un peligro: transformarse en destrucción y abolición. Aunque la música nunca es trágica, puede despertar en nosotros las ganas de morir, aunque sean las de morir feliz. La Maga, la Eterna, Elsa, apuntan a ello, y no porque despierten instintos de muerte, sino porque la máquina musical en que deviene su pensamiento promete una dicha tan inmensa que despierta una suerte de exasperación cuando no se alcanza. Exasperación que, como le sucede a Oliveira, puede conducir a "ese instante terriblemente dulce en que lo mejor, sin lugar a dudas, hubiera sido inclinarse apenas hacia fuera y dejarse ir, paf se acabó" (509).

En esta escena, lo que queremos resaltar -más allá si el álter ego de Cortázar salta o no salta desde la ventana en que se encuentra- es la atracción irresistible que forman las figuras de Traveler y la Maga- Talita (Manú y la Maga) mirándolo desde allá abajo en el patio empedrado. Dejarse ir para morir feliz, piensa Oliveira. La seducción de ese pensamiento que venimos llamando musical, atrae, podríamos decir con Rayuela, como la superficie de un agua temible y alucinante a la vez: "yo volvía a sentar el falso orden que disimulaba el caos, a fingir que me entregaba a una vida profunda de la que solo tocaba el agua terrible con la punta del pie" (234). Los enunciados vida profunda y agua terrible apuntan, en nuestro sistema, a las ninfas, en rigor, a una escena originaria sobre ellas narrada por Calasso:

\begin{abstract}
"Cuando lo héroes desembarcan Quíos, Hylas, el encantador, amante de Heracles, se aleja para buscar agua. Así llega a una fuente en el preciso momento en que una ninfa está emergiendo, como si en su soledad se repitiera en él la escena descrita por Cátulo. La ninfa es arrollada por un deseo violento. Se acerca a Hylas cuando el joven va a sacar agua. Le rodea el cuello con un brazo y para besarlo en la boca. Pero su brazo derecho lo empujaba hacia abajo y lo hacía meterse en medio de la olla" (36).
\end{abstract}

Importa sobremanera comparar, para corroborar que acá también hay ninfas, el anterior relato griego con otro relato que recogimos en las cordilleras de Antioquia, Colombia: 
“dos niños regresan corriendo asustados a la aldea y allí cuentan que fueron a bañarse a una laguna del bosque, cuando llegaron allí vieron a la mamadre (una atiseinekum) desnuda y tan bien peinada, con una cinta en el pelo, y con señas los invitaba al agua, pero huyeron, pues la mamadre los quería ahogar. Tirándolos con el brazo hacia abajo, así los quería ahogar".

Volvemos a Oliveira, quien precipitándose del tercer piso revela que el delirio que viene de las ninfas puede ser sin retorno. Tal como el caso de Hylas, el abrazo de la ninfa puede ser mortal, no por ella, sino porque el mundo que habita es tan profundo y bellamente distinto que no hay otra manera de acceder que ahogándose o arrancándose los ojos: "Déjate caer, golondrina, con esas filosas tijeras que recortan el cielo de Saint-German des Prés, arranca estos ojos que miran sin ver... y de que llueva aquí dentro, de que si por fin empieza a llover, a oler tierra, a cosas vivas, si, por fin, a cosas vivas" (236).

A fin de cuentas, precipitarse en la "olla" empujado por el brazo de las ninfas, o por una de sus variantes, dejarse arrancar los ojos por ellas, es alcanzar los extremos del delirio. Allí donde la muerte huele a "cosas vivas".

Pero el pensamiento musical de las ninfas no se detiene en escenas, fragmentos o episodios de los textos mencionados en el análisis. Abarca la estructura misma de las novelas, como lo mostramos a continuación.

Museo de la novela de la Eterna tiene la estructura propia de un "Preludio". Sus cincuenta y nueve prólogos equivalen musicalmente a "aquello que se toca o canta para ensayar la voz, probar los instrumentos o fijar el tono antes de comenzar la ejecución de una obra musical". Macedonio prueba los procedimientos, ensaya las diversas voces narrativas y fija el tono del relato que vendrá a continuación.

Rayuela, por su parte, tiene la composición de una obra de jazz. Narrativamente se trata de un tema central, la búsqueda de la Maga, “¿Encontraría a la Maga?", en torno al cual se ejercitan una serie de improvisaciones, al modo del músico Charlie Parker de El perseguidor.

Y, por último, Los siete locos puede leerse y "oírse" como una serenata de Mozart, la Haffner. Recordemos que un personaje crucial de la novela, aquél que en la intimidad se hacía llamar el "Rufián Melancólico", lleva el apellido Haffner, Arturo Haffner. Relación intertextual que justifica abiertamente nuestra propuesta. 
En la serenata Haffner, Mozart "realiza un trabajo especulativo sobre los géneros musicales de su tiempo. En ella mezcla estilos, recurre a la hibridación de géneros, introduce variantes distintas del mismo tipo de danza, injerta diversos formatos, etc." (López Cano).

¿Qué mejor descripción del estilo de Roberto Arlt? Hibridación de géneros, introducción de variantes, injerto de diversos formatos. Tal como escribe Piglia "La ficción de Roberto Arlt es su estilo... la ficción de Arlt está hecha en el plano lingüístico del mismo material con que construye sus temas. Por eso dan risa los que dicen que es escritor a pesar de su estilo" (Piglia, Respiración 175).

Estilo que, precisamente, se puede considerar como la alteridad máxima de la vigilancia panóptica, pues ésta tiene por función y obsesión evitar la mezcla, imponer un formato, someter los cuerpos y, con ellos, la mente, a la geometría de lo lineal. Frente a la extraña, y perversa, obsesión de vigilar surgen las ninfas y el devenir que provocan. Delirio musical, pensamiento musical de náyades, alseides y dríades. Fascinante pensamiento en el que no existe una relación inmediata entre significante y significado. Estupendo delirio. En las novelas leídas, ese delirio es la narración. Narración que fractura, precisamente, la geometría de la novela panóptica y... cuando caen los muros de la prisión brotan vertiginosos los devenires. Entonces, el texto muestra el deseo, la mezcla de los cuerpos, la pasión, es decir, algo muy parecido a ser feliz.

\section{BIBLIOGRAFÍA}

Arlt, Roberto. Los siete locos. Buenos Aires: Losada, 1996.

Baudrillard, Jean. El crimen perfecto. Barcelona: Anagrama, 1996.

Bombal, María Luisa. "El árbol”. Antología de cuentos hispanoamericanos. Mario Rodríguez (compilador). Santiago: Editorial Universitaria, 2005. 208-214.

Borges, Jorge Luis. "El escritor argentino y la tradición". Obras completas. Buenos Aires: Emecé Editores, 1998. 273.

“El aleph”. Obras Completas. Buenos Aires: Emecé Editores, 1998. 186.

Bukoswki, Charles. "Decadencia y caída”. Música para cañerías. Barcelona: Anagrama, 2000. 32-36.

Calasso, Roberto. La locura que viene de las ninfas y otros ensayos. México: Sexto Piso, 2004.

Cortázar, Julio. Rayuela. Buenos Aires: Ediciones Cátedra, 2000. 
Darío, Rubén. "La ninfa”. Antología de cuentos hispanoamericanos. Mario Rodríguez (compilador). Santiago: Editorial Universitaria, 2005. 115-119.

Deleuze, Gilles. Crítica y clínica. Barcelona: Anagrama, 1996.

Deleuze, Gilles; Félix Guattari. Mil mesetas. Valencia: Pre-textos, 1997.

Fernández, Macedonio. Museo de la novela de la Eterna. México: Fondo de Cultura Económica, 1996.

Falcon et ál. Diccionario de mitología. Gredos: Madrid, 2000.

Foucault, Michel. Vigilar y Castigar. Madrid: Siglo XXI Editores. 2000.

González, Horacio. Arlt. Politica y Locura. Buenos Aires: Ediciones Coligue, 1996.

López Cano, Rúben. "Ludwing van Beethoven, Cuarta Sinfonía en Si bemol Mayor. Op. 60. Mozart serenata en Re Mayor K. 250 "Haffner". En Notas al programa de conciertos de la orquesta de Castilla y León. Castilla 2001 - 2002”. Castilla, 2001.

Nabokov, Vladimir. Lolita. Barcelona: Anagrama, 2002.

Piglia, Ricardo. Respiración artificial. Buenos Aires: La Nación, 2000.

Formas breves. Buenos Aires: Termas Grupo Editorial, 1999.

Rodríguez, Mario, et ál. Utopía y mentira de la novela panóptica. Concepción: Editorial U. de Concepción, 2006.

Rodríguez Mario y Gilberto Triviños. (editores). Utopía y mentira de la novela panóptica. Concepción: Sello Editorial de la U. de Concepción, 2006.

Rodríguez, Mario y Rodríguez, José Manuel. "Teresa o el terremoto de Lima. Historia de una cruza". Crítica y creatividad. Dieter Oelker, Gilberto Triviños, editores. Concepción: Editorial Universidad de Concepción, 2007. 291-309. 